\title{
Sedimentology, Structure and Depositional Environments of the Subsurface Cretaceous, North Sinai, Egypt Using Well Logs
}

\author{
Fouad Shaaban1, Amani Bourselli², Adam El-Shahat', Mostafa El-Belqasi' \\ ${ }^{1}$ Geology Department, Faculty of Science, Mansoura University, Mansoura, Egypt \\ ${ }^{2}$ Science Department, College of Basic Education, PAAET, Kuwait \\ Email:ahmedbufarsan@gmail.com
}

How to cite this paper: Shaaban, F., Bourselli, A., El-Shahat, A. and El-Belqasi, M. (2020) Sedimentology, Structure and Depositional Environments of the Subsurface Cretaceous, North Sinai, Egypt Using Well Logs. International Journal of Geosciences, 11, 37-57.

https://doi.org/10.4236/ijg.2020.113004

Received: January 2, 2020

Accepted: March 2, 2020

Published: March 5, 2020

Copyright $\odot 2020$ by author(s) and Scientific Research Publishing Inc. This work is licensed under the Creative Commons Attribution International License (CC BY 4.0).

http://creativecommons.org/licenses/by/4.0/

(c) (i) Open Access

\begin{abstract}
A complete set of well logs was used to study the sedimentology, structural and depositional environments of the subsurface Cretaceous rocks of northern Sinai, as a promising hydrocarbon province in Egypt. The sedimentological interpretations of well logs show sedimentary sequence of the Early Cretaceous, represented by the Neocomian, Aptian and Albian, which is composed mainly of shales and marls with minor carbonate and sandstone intercalations. Based on the $\mathrm{Th} / \mathrm{K}$ ratios, the argillaceous sediments are composed of illite, montmorillonite and micas with little amounts of glauconite and chlorite. The environmental interpretations revealed sedimentological environments vary from estuarine to lagoonal and backreef of the Barremian-Aptian rocks, and from continental to estuarine in the Aptian-Albian. By contrast, the Late Cretaceous rocks, represented by the Cenomanian, Turonian, Santonian and Maastrichtian, are mainly composed of carbonates with few shale and marl intercalations. This sequence was accumulated under lagoonal to neritic and bathyal environments. The structural interpretations of well logs show that the Cretaceous section attains a wide range of dip magnitudes and dispersed azimuths all over the study area, which is probably attributed to tectonic and sedimentological processes. The inherited structural complexities indicate possible rejuvenations along old fault planes and rotation of the faulted blocks.
\end{abstract}

\section{Keywords}

North Sinai, Cretaceous, Sedimentology, Structure, Environment, Well Logs

\section{Introduction}

The geological framework and structural evolution of the North Sinai have been 
the subject of considerable research e.g. [1] [2] [3]. Five regional unconformities were observed and mapped on seismic sections in the study area. These tectonosequence boundaries reflect major changes in regional tectonic settings [1]. Most of the mapped structures in offshore North Sinai are located within five NE-oriented inverted structures, whereas the intervening areas are undeformed or only slightly deformed. The inverted structures are controlled by major deep-seated reverse faults with doubly plunging anticlines in which there is thick syn-extensional strata in the core. Three phases of structural deformation affected the Mesozoic-Cenozoic succession in offshore North Sinai. Phase 1 is a Jurassic to Early Cretaceous rifting phase, which has been indicated in this study to have taken place in several pulses during the Late Jurassic, Neocomian, and Aptian-Santonian times. Phase 2 is a post-Santonian to Middle Miocene inversion phase, and Phase 3 represents the Neogene extension phase. Despite a relatively complex history, the Phanerozoic geological framework of Egypt is highly prospective for oil and gas and eight major tectono-stratigraphic events have created multiple reservoir and seal combinations [4].

The North Sinai area was not considered as a potential oil or gas province before 1982. In that year, gas discoveries were made in the offshore Port Fouad-1, Wakar-1 and Kersh-1 wells, while oil was discovered in the Tineh-1 and Mango-1 wells (Figure 1). Potential reservoir rocks and seals in northern Sinai are widely distributed throughout the geological section, and Carboniferous, Jurassic, Triassic and Early Cretaceous open- to shallow-marine sediments contain potential reservoir, source and seal rocks. Organic-rich shales interbedded within Triassic carbonates and Neocomian shales have proved to be effective oil

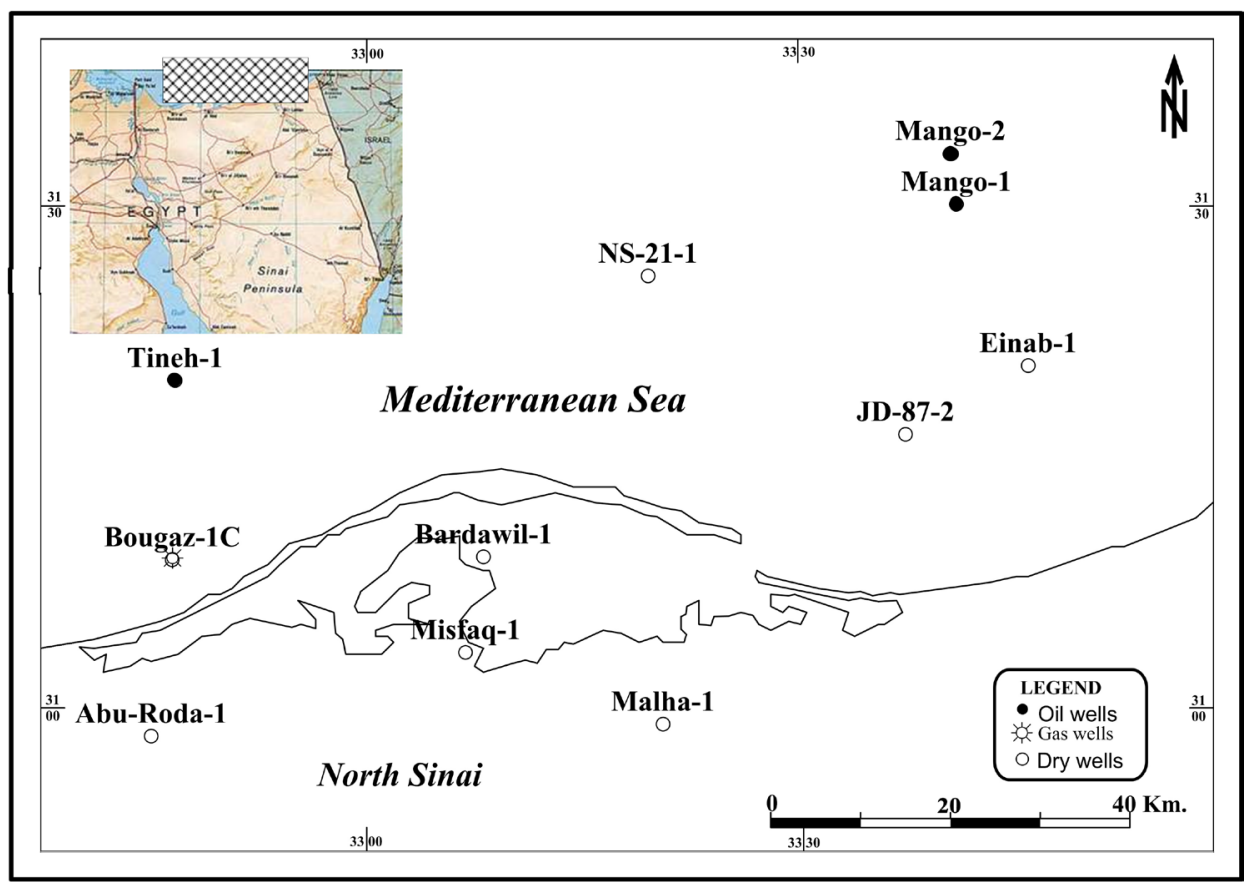

Figure 1. Location of the study area and expanded map showing the well locations (modified after Yousef, et al., 2010). 
source rocks, while Middle Jurassic carbonates and Oligocene shales are potential gas-prone source rocks [5].

The study area comprises the off- and on-shore parts of northern Sinai located between Lat.'s $30^{\circ} 50^{\prime} \mathrm{N}$ and $31^{\circ} 40^{\prime} \mathrm{N}$ and Long.'s $32^{\circ} 35^{\prime} \mathrm{E}$ and $33^{\circ} 50^{\prime} \mathrm{E}$ (Figure 1). The purpose of this paper is to evaluate the geological context of the subsurface Cretaceous sequence of North Sinai, as a promising hydrocarbon province, with particular emphasis to the depositional environments, sedimentological and structural characteristics.

\section{Geological Background}

The exposed Cretaceous sediments constitute a good part of the northern Sinai folded belt; e.g., Minsherah, Maghara, Halal, Arief El-Naga, etc. The Early Cretaceous rocks crop out in northern Sinai in the flanks of the Maghara anticline, particularly at the Rizan Aneiza. This section is made of more than $250 \mathrm{~m}$ of variegated sandstones with fossiliferous marly beds at base of the section. Oolitic ferruginous limestones and fossiliferous shales follow the sandstones, with faunal assemblage indicating an Aptian age. Conformably overlying these beds, there is a thick section of oolitic sandy limestones with shale and marl interbeds carrying fossils of Albian age [6].

The sedimentary cover in North Sinai ranges from Carboniferous to Recent (Figure 2). The oldest rocks penetrated by drilling in northern Sinai are Jurassic, and a major angular unconformity separates them from the overlying lowermost Cretaceous. In the offshore area, the sedimentary cover increases in thickness from $1800 \mathrm{~m}$ to more than $7600 \mathrm{~m}$, related to the transition from continental to oceanic crust.

The subsurface section of the Early Cretaceous (Neocomian, Aptian and Albian) varies in thickness and lithology, from well to another and from the on- to the offshore of northern Sinai. This section has a complex lithological nature that composed of shales, marls, limestones and occasionally sandstones. However, the thickness distribution (Figure 3(a)) shows a general increase toward the $\mathrm{NE}$, recording the maximum value of $1749 \mathrm{~m}$ in the Mango-1 well, while decreases $\mathrm{W}$ and SW wards, recording the minimum value of $51 \mathrm{~m}$ in the Tineh-1 well.

By contrast, the Late Cretaceous (Cenomanian) outcrops are of wide distribution in northern Sinai. They form the main bulk of the Gebel Halal, Gebel Yelleg and most other anticlinal structures of northern Sinai. The Late Cretaceous lies directly on the Nubia Sandstone or directly on non-clastic Albian strata in the outer flanks of the Maghara dome. These strata consist essentially of resistant limestone and dolostone beds, with sandstone interbeds and shales, particularly at the base. The upper boundary of Cenomanian is difficult to determine, but it is taken tentatively at the top of the "ammonite bed". This bed is an excellent marker and can be followed in the field for long distances. The Late Cretaceous (Turonian-Senonian) covers a large tract and consists of a lower section, of $\mathrm{Tu}$ - 
ronian age, and an upper one presumably of Santonian. The Turonian section is composed of hard dolomitized limestones with some flint bands. The beds are commonly hard and resistant, occupying many of the topographic highs and flanking many structures. The Santonian section consists of marly limestones and a number of chalky limestone interbeds containing some flint

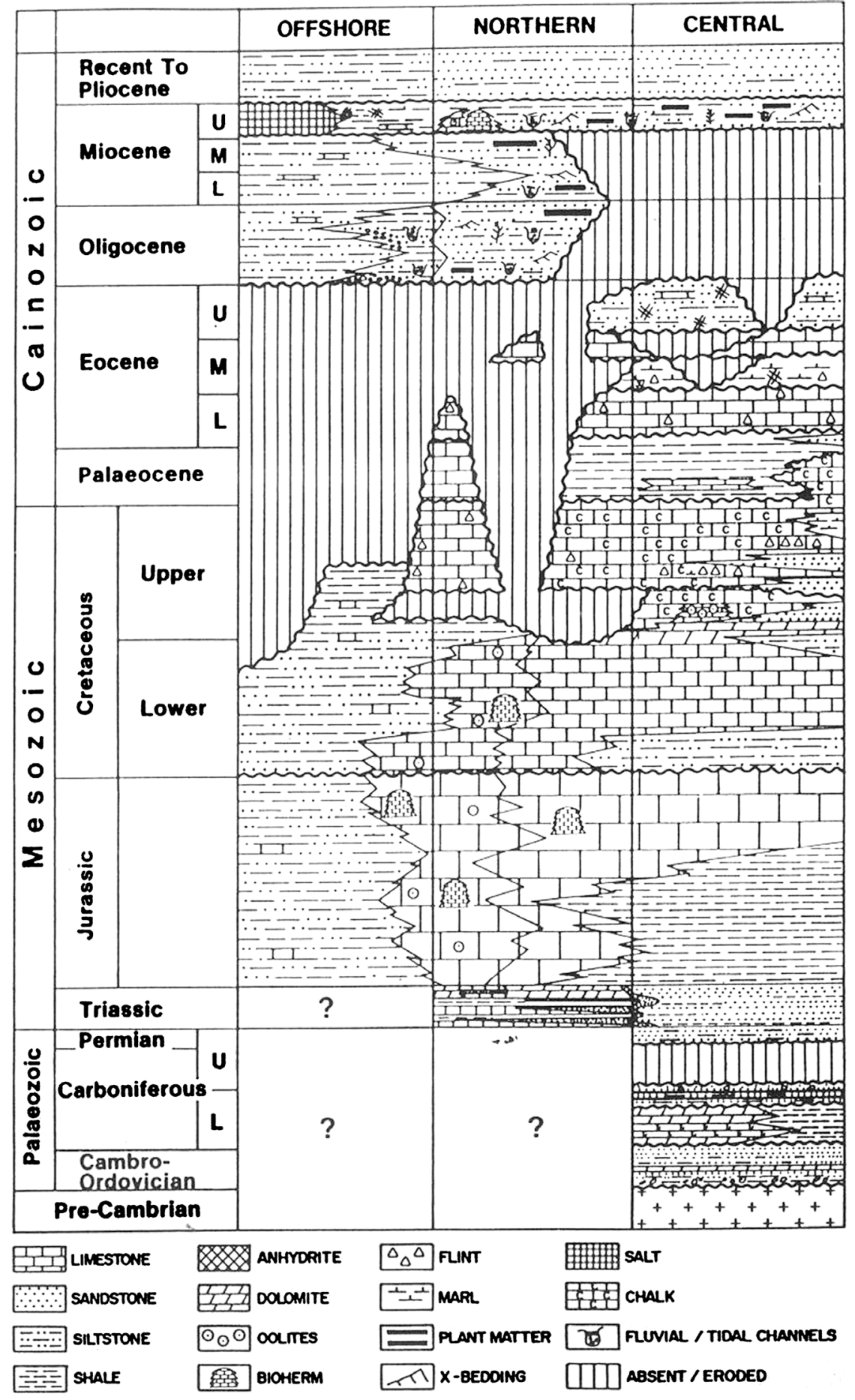

Figure 2. Generalized chronostratigraphic column of the central, northern and offshore Sinai [4]. 
(b)

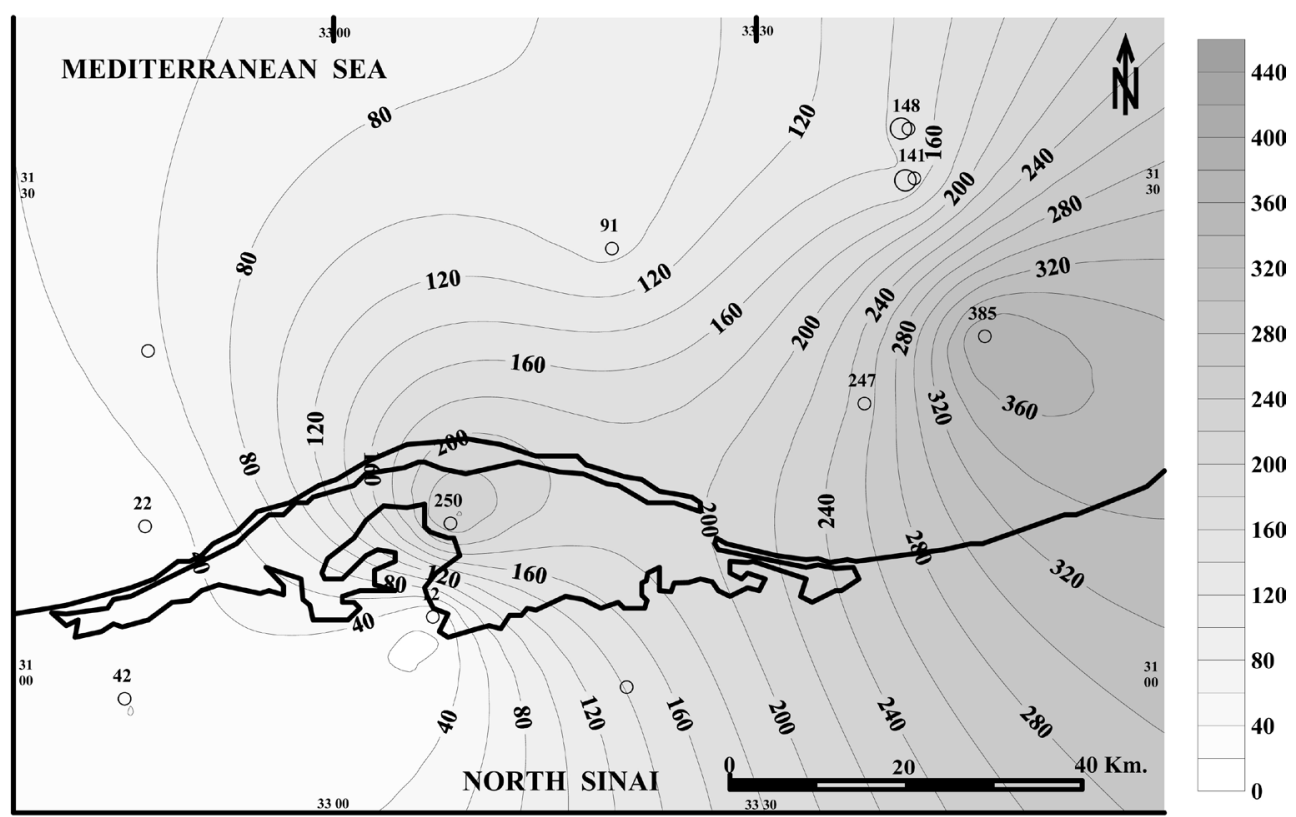

(a)

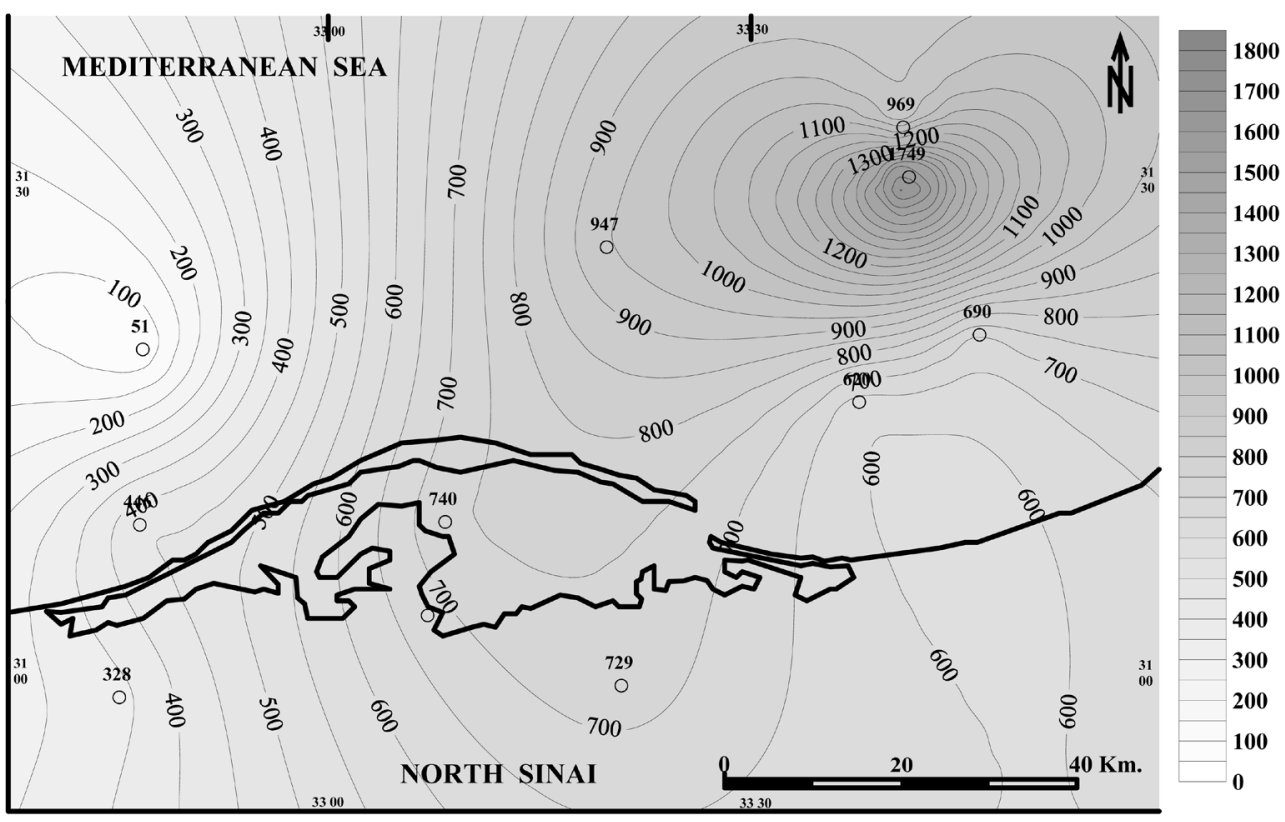

Figure 3. Isopach maps of the (a) Early Cretaceous and (b) Late Cretaceous sections.

bands. The Santonian strata are less resistant and occupy large tracts of lowlands around many mountains and hills.

The subsurface section of the Late Cretaceous, represented by the Cenomanian, Turonian, Santonian and Maastrichtian, is also variable in thickness all over the study area but of relatively homogenous lithological characteristics, which are mainly carbonates. The isopach map of the Late Cretaceous (Figure 3(b)) shows lower thickness values than those of the Early Cretaceous but with a distribution similarity with that of the Early Cretaceous (Figure 3(a)), which suggests that Laramide movements were in progress during that time. However, 
the structural framework of northern Sinai, resulting from the Pelusium line and the Bardawil escarpment influences the pattern of the thickness distribution, producing the strong thickness variations. The maximum thickness of the Late Cretaceous (Figure 3(b)) is $385 \mathrm{~m}$, recorded in the Einab-1 well, which decreases gradually toward the $\mathrm{W}$ and $\mathrm{SW}$ recording the minimum value of $12 \mathrm{~m}$ in the Misfaq-1 well. Occasionally, the Late Cretaceous is disappeared as in the Tineh-1 well, and the Early Cretaceous is overlain by sediments younger than the Late Cretaceous.

The shale and carbonates represent the frequent lithofacies of the subsurface Cretaceous section, which reflect their importance in the petroleum system of the study area. The isopach map of the subsurface Cretaceous shales (Figure 4(a)) shows thickness values increasing NE ward with a maximum value of 1443 $\mathrm{m}$ in the Mango-1 well. The shale thickness decreases $\mathrm{W}$ and SW wards recording the minimum value of $51 \mathrm{~m}$ in the Tineh-1 well. The sand/shale ratio map (Figure 4(b)) shows values ranges from zero S and SW of the study area to about 0.5 toward NE ward, which confirms the predominance of shale within the Cretaceous section. The isopach of the carbonates facies (Figure 4(c)) shows thickness values range from $10 \mathrm{~m}$ to $321 \mathrm{~m}$. [7] based on organo-source and pyrolysis data, concluded that the Cretaceous shales attain good levels of petroleum potential and its kerogen is mainly of type III with few quantities of type II. This indicates gaseous generating potential (not excluding oil) of northern Sinai.

Tectonically, the NE Egypt underwent regional compression, during the Early Cretaceous to Eocene, as a result of the subduction of the African-Arabian Plate beneath the Euro-Asiatic margin [2]. During the Oligocene-Miocene, major faults or "hinge lines" related to the previous deformational phases were re-activated and normal fault systems were generated with WSW-ENE orientations. These faults are crossed by others which are oriented NNW-SSE [3].

Five regional unconformities were observed and mapped on seismic sections in the off-shore area. Most of the mapped structures in offshore North Sinai are located within five NE-oriented inverted structures, whereas the intervening areas are undeformed or only slightly deformed. The inverted structures are controlled by major deep-seated reverse faults with doubly plunging anticlines in which there is thick syn-extensional strata in the core.

Later extension caused repeated rejuvenation of the faults. Taking the Oligo-Miocene sedimentary evolution into account, it can be noticed that major structural reorganization occurred twice: once during the middle Oligocene, and once during the middle Miocene. Two tectonic-related sedimentary super cycles can be recognized within the Oligo-Miocene succession: the first started during the late Oligocene, the second in the Serravallian [6].

The North Sinai area also underwent regional compression during the Late Cretaceous to Eocene as a result of the subduction of the African-Arabian Plate beneath the Euro-Asiatic margin [8]. This caused faulting in the study area and overthrusting of the Syrian Arc towards the south. The Syrian Arc fold belt 

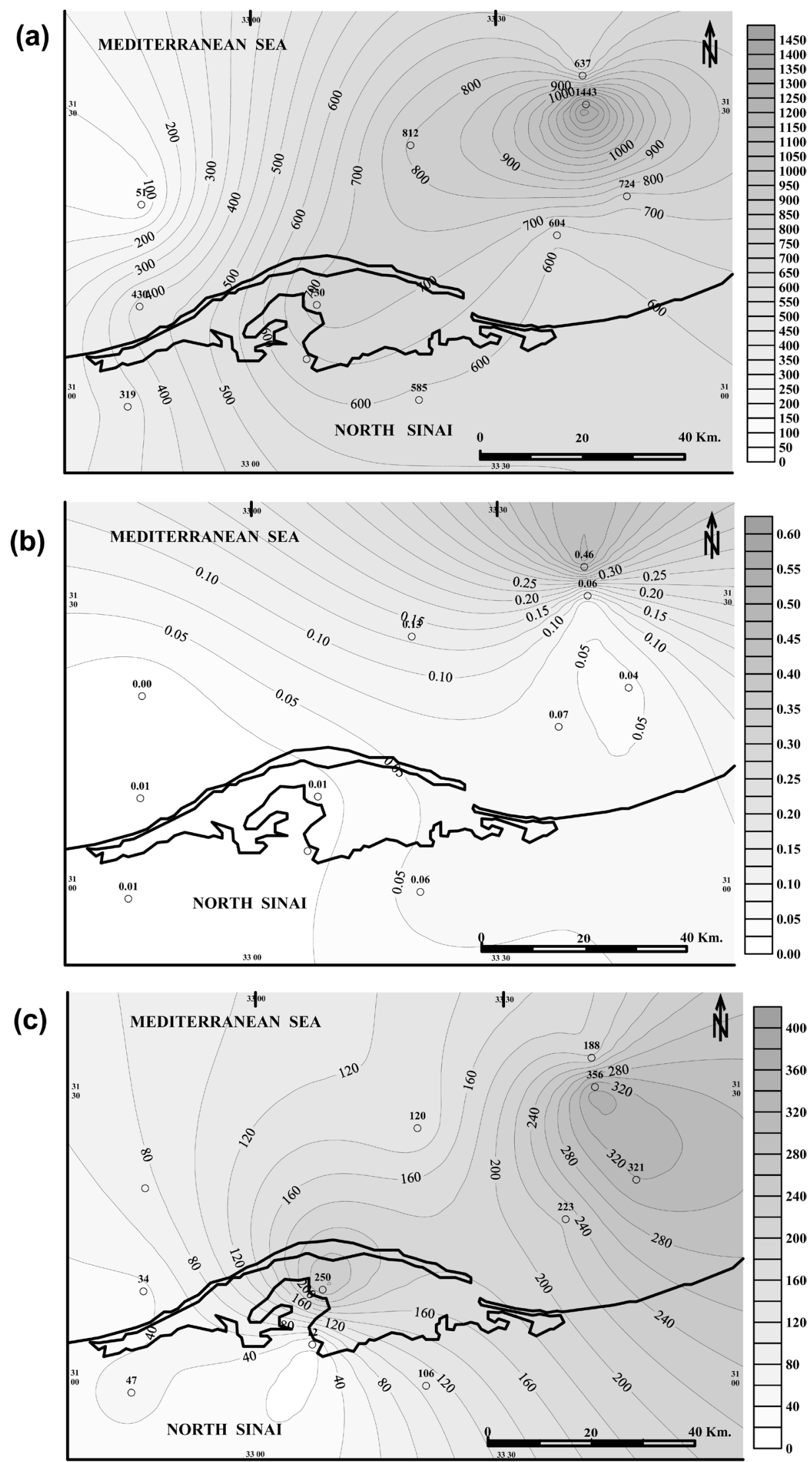

Figure 4. Isopach map of the (a) Cretaceous shale, (b) Cretaceous Sand/Shale ratio and (c) Cretaceous carbonates. 
strikes NE-SW in North Sinai. It consists of asymmetric anticlines with gently dipping NW flanks and steep, in places overturned or even overthrusted SE flanks. The fold belt is progressively bent to the north; further north, these "Syrian Arc" structures are hidden beneath the Quaternary coastal plain and continental shelf deposits [8]. A large number of ENE trending faults have been recorded parallel to the fold axes, especially in the hinge belt [1]. Post-Eocene movements brought northern Sinai above sea level and the region underwent intense erosion during the Oligocene.

A number of latitudinal and longitudinal cross sections have been constructed, for verifying the subsurface structural characteristics in the study area and represented by Figure 5. These sections show that the area was, also, intensely faulted and accordingly, the Cretaceous section appears to be of erratic thickness and distribution.

The paleorelief map of the Early Cretaceous basin (Figure 6(a)) shows bottom topography sloping $\mathrm{N}$ - and NW wards, recording the maximum depth of 4561 $\mathrm{m}$ in the NS21-1 well. The minimum depth is $1039 \mathrm{~m}$, recorded SE ward in the Malha- 1 well. This distribution pattern indicates that the basin of the Early Cretaceous was affected by a regional faulting trending NE-SW. The structural contour map on the top of the Early Cretaceous section (Figure 6(b)) shows a similar distribution pattern concerning the highs and lows, which reflects a regular sedimentation pattern during that time.

The structure contour map on top of the Late Cretaceous shows a narrow, closed and elliptical to elongate contour pattern with an axis trending NE-SW (Figure 6(c)). The maximum recorded depth is $3524 \mathrm{~m}$ in the NS21-1 well, which decreases rapidly on both sides of the basin boundary to a minimum value of $1708 \mathrm{~m}$ in the Einab-1 well. The Late Cretaceous section is absent in the Malha- 1 and in the Tineh-1 wells. This suggests the possible rejuvenation of the earlier structural folding and/or faulting causing non-deposition and/or erosion of the Late Cretaceous section on the structural high blocks.

The distribution of the Cretaceous thickness and facies indicates a folding movement (Alpine) began at least as early as the Cenomanian and continued intermittently throughout the uppermost Cretaceous. The movement was responsible for the development of the NE Syrian Arc System of folds that crosses most of northern Sinai and was strong enough to bring many of the folds above sea giving rise to variable stratigraphic breaks. During the Late Cretaceous an extensive transgression overstepped northern Sinai, and deeper water conditions prevailed over that area.

\section{Materials and Methods}

The materials comprise well logs of eleven exploratory wells distributed off- and onshore the northern Sinai (Figure 1). The logs include dipmeter (DHT and SHDT), natural gamma ray spectrometry (NGS), resistivity $\left(\mathrm{R}_{\mathrm{msfl}} \& \mathrm{R}_{\mathrm{Ild}}\right)$, sonic (BHC), neutron (CNL) and density (FDC) logs. Processing and illustrations of 
the log data were done analytically and the interpretations were done utilizing a number of structural, isopach and isolith contour maps.

The high-resolution dipmeter logs have the advantage to detect very thin events which can be related to textural and structural features. It has high vertical

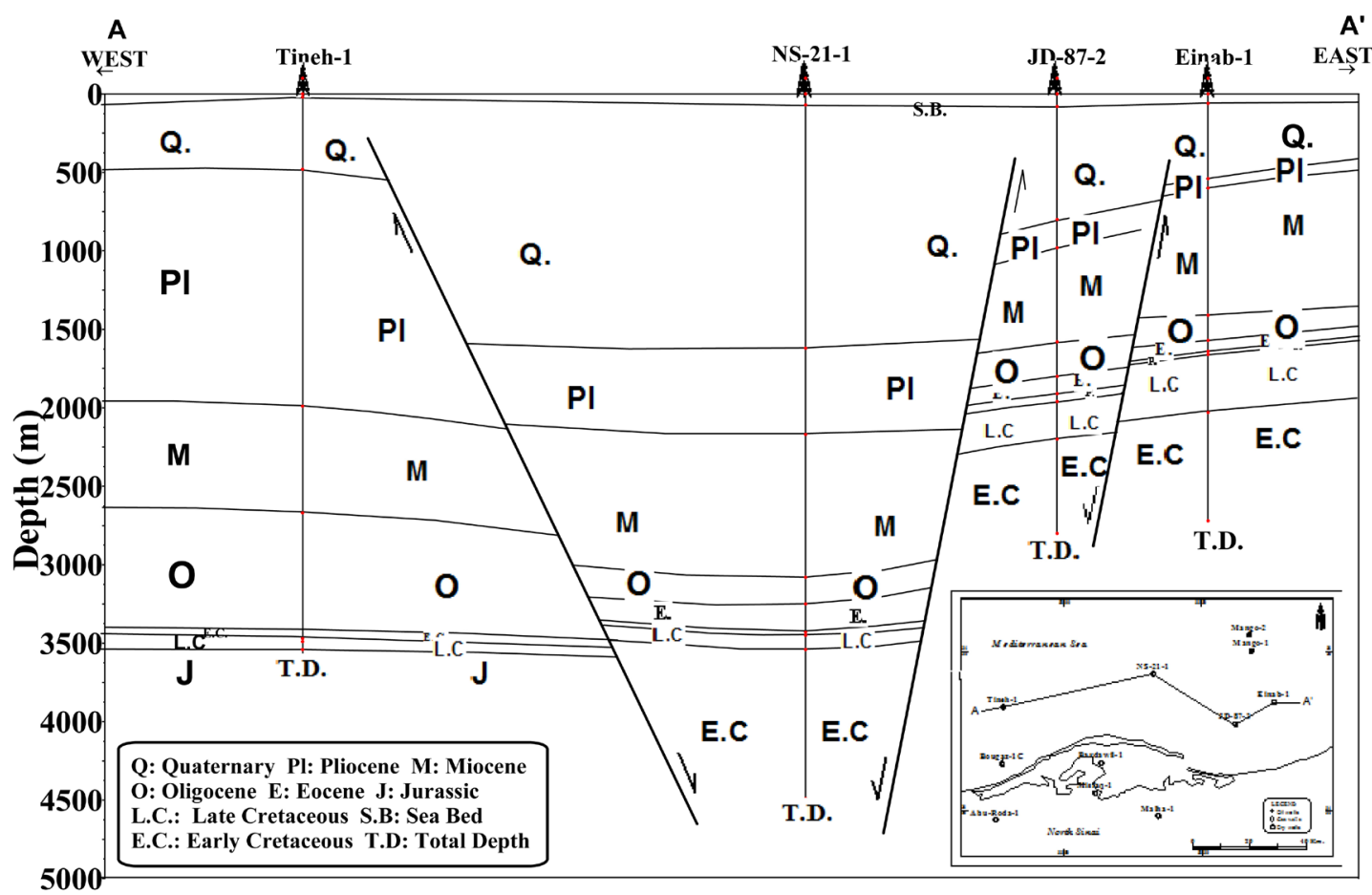

(a)

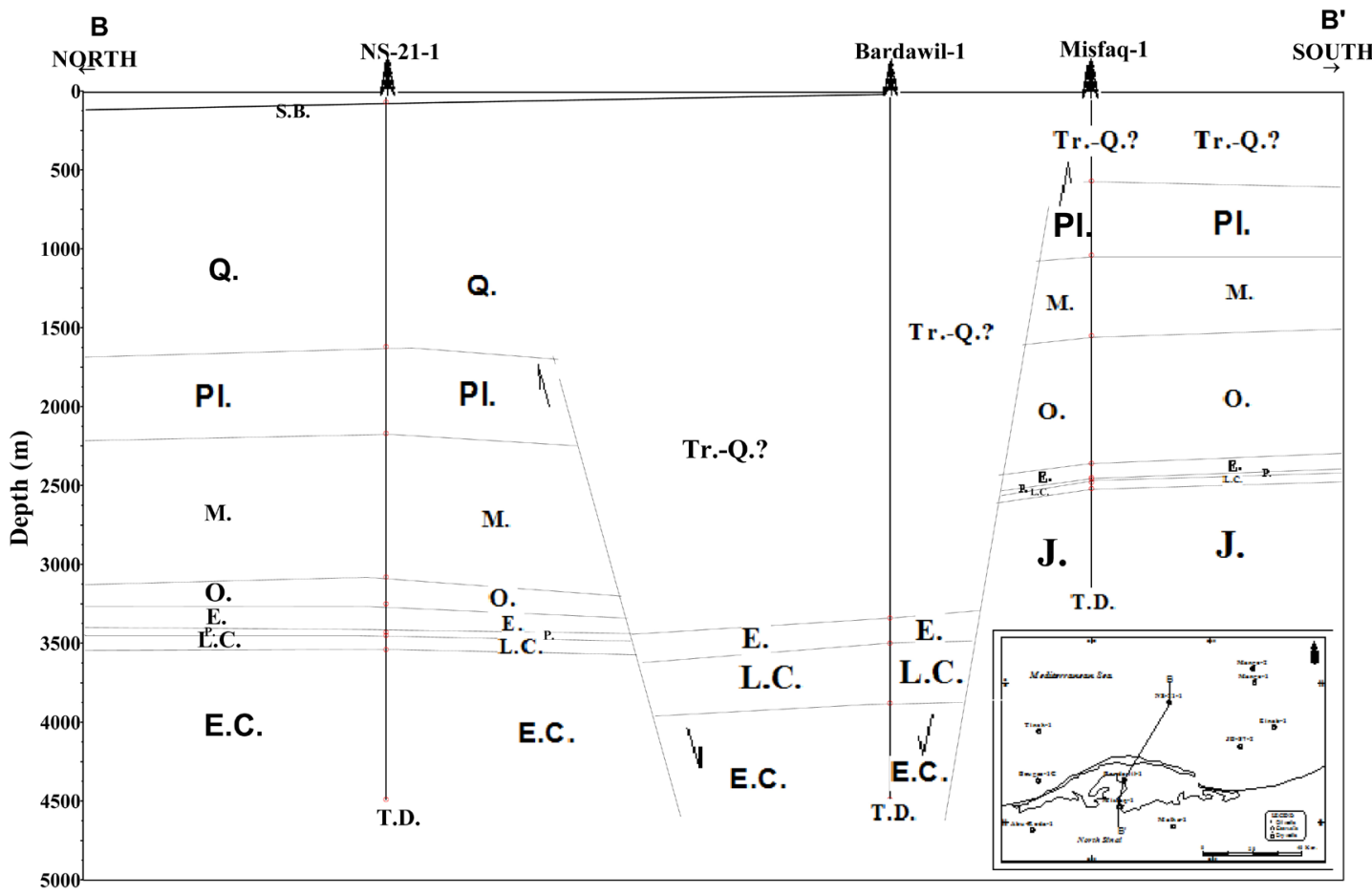

(b)

Figure 5. Structural cross-sections along profiles A-A' (a) and B-B' (b). 
(a)

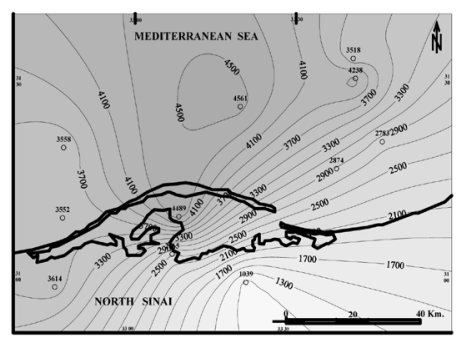

(b)

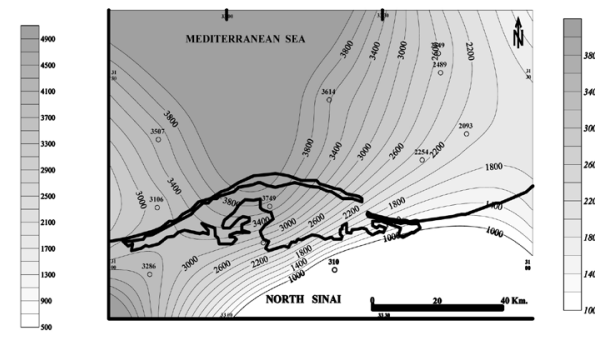

(c)

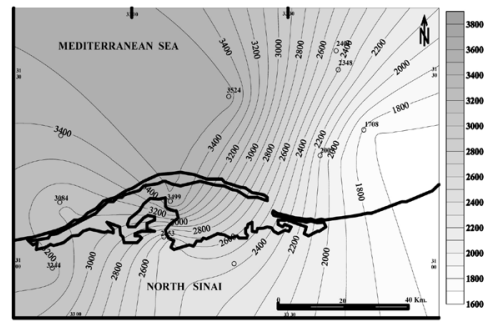

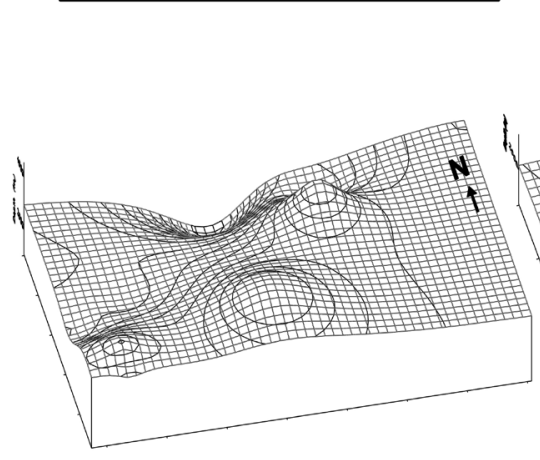
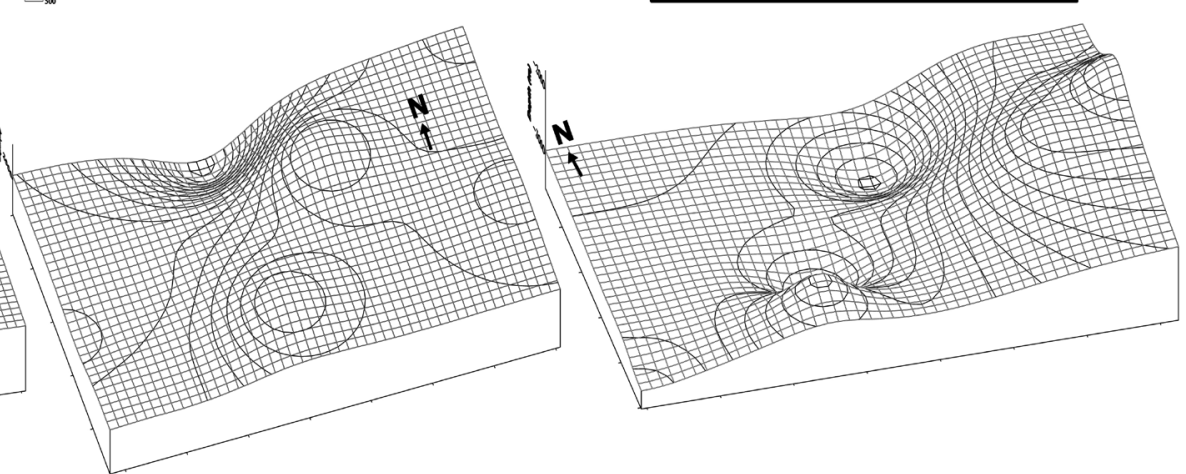

Figure 6. Paleorelief map and 3-D of the Early Cretaceous basin (a), depth contour maps and 3-D plots on the tops of the Early Cretaceous (b) and the Late Cretaceous (c).

resolution that can measures apparent thickness of events $(<1 \mathrm{~cm})$ as long as they are conductive in resistive rock units [9]. Two methods are used for interpreting the dipmeter data, these are the graphical (dip grouping) and the analytical (stereographic plotting) techniques. The dip-grouping (graphical) technique depends on dip patters that can be organized into four groups and coded by color; Green (constant dip magnitude and azimuth with increasing depth), Blue (decreasing dip magnitude and constant azimuth with increasing depth), Red (increasing dip magnitude and constant azimuth with increasing depth) and Yellow (random dip magnitude and azimuth). Each dipmeter pattern has specific structural, stratigraphical and sedimentological interpretation. However, the interpretation of dipmeter data was correlated with those interpreted from the other logs and lithological information. The stereographic plotting technique allows a more detailed analysis of dipmeter data giving a precise reconstruction of traversed structures [10].

The gamma ray spectrometry logs are interpreted, utilizing the ratio curves, for determining the geochemical facies and the depositional environments of the studied interval. A qualitative approach to clay mineral identification has been proposed by, who suggested that clay mineral species along with feldspar and evaporites could be identified simply by their Th/K-ratios. However, the Th/U logs offer an easy way for distinguishing the continental, mixed and marine environments. This is because the distribution of thorium and uranium in sedimentary rocks is largely determined by the oxidation and leaching of uranium during weathering and the distribution of resistate minerals containing a high concentration of thorium and uranium [11]. 


\section{Results and Discussions}

\section{1) Environmental and Facies Interpretations}

The NGS, HDT and the SHDT logs were used for defining the depositional environments and facies characteristics of the subsurface Cretaceous section in the study area. The principal use of the NGS logs (SGR, CGR, Th, U, K logs and their ratios) is the identification of the depositional environments of shales. The affinity of uranium for shales of marine origin has been documented contrasted with the affinity of thorium for terrestrial sediments. Consequently, it has been proposed that the content of uranium in shales compared with that of thorium gives an index of the amount of marine influence in the environment of deposition. Marine shales should have a low $\mathrm{Th} / \mathrm{U}$ ratio $(<2)$ whereas the reverse is true $(>6)$ for the continental shales [12]. Application of these rules revealed that the majority of the Early Cretaceous shales are of continental to marine origins in the Jd87-2, the Bardawil and the NS21-1 wells (Figures 7(a)-(c)). These shales

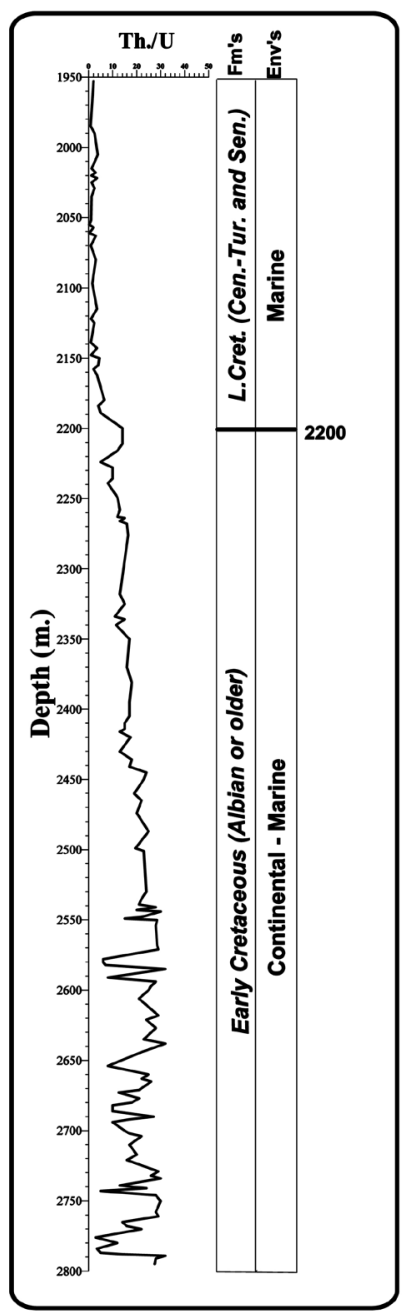

(a)

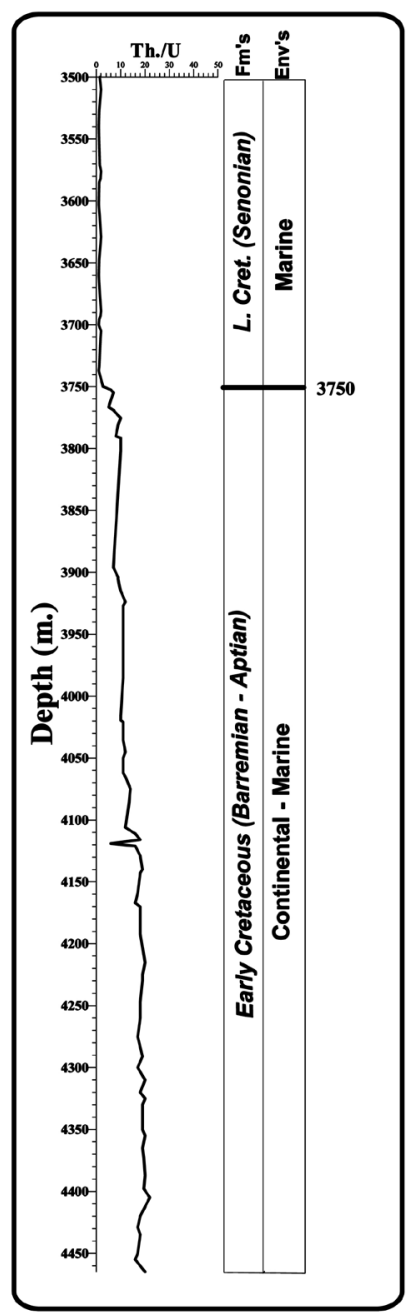

(b)

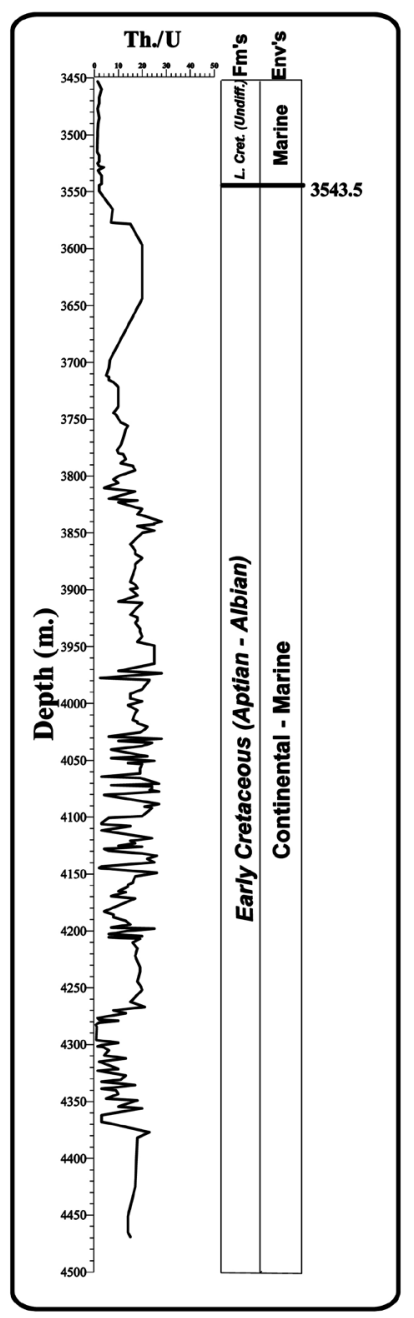

(c)

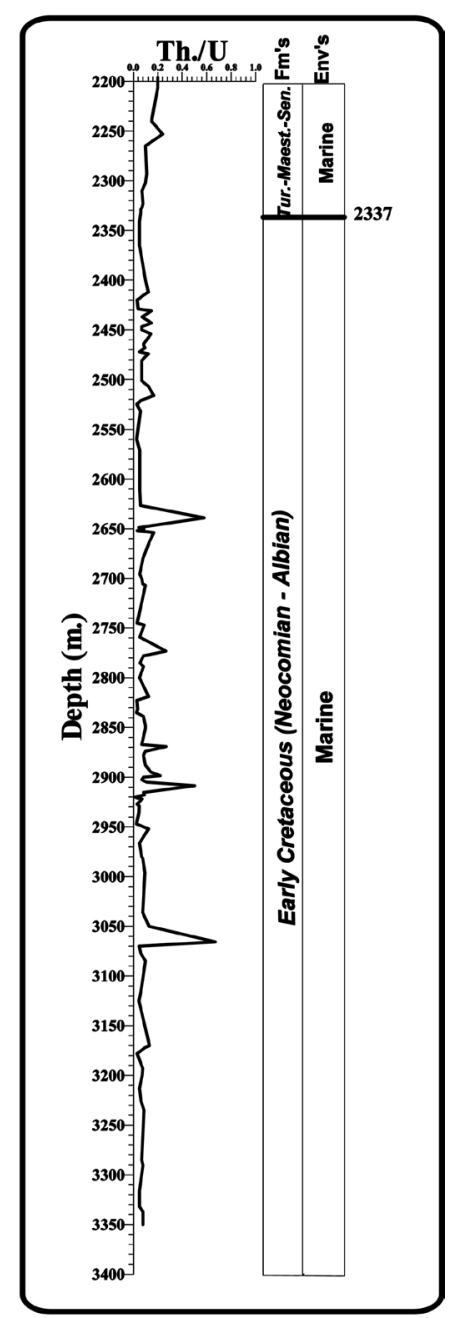

(d)

Figure 7. Identification of the Late Cretaceous depositional environments using the Th/U-depth crossplot in the Jd87-2 (a), Bardawil (b), NS21-1 (c) and Mango-1 (d) wells. 
are characterized by relatively high $\mathrm{Th} / \mathrm{U}$ ratios $(>18)$. Only in the Mango-1 well, the Early Cretaceous section attains a relatively low $\mathrm{Th} / \mathrm{U}$ ratio $(<0.4)$ (Figure $7(d)$ ), suggesting a marine origin. The low $\mathrm{Th} / \mathrm{U}$ ratios of the Late Cretaceous shales in the studied wells (Figures 7(a)-(d)) suggest the prevalence of marine origin.

The graphical dipmeter interpretation is based on the dip-grouping and pattern recognition method [9]. Consequently, a succession of Red, Blue, Green and Yellow patterns has been verified within the Cretaceous section of the studied wells, examples are shown in Figure 8 and Figure 9. Interpretation of these patterns is correlated with the resistivity logs. An example of these correlation illustrates an interval of the Early Cretaceous section of the Mango-1 well (Figure 10). This

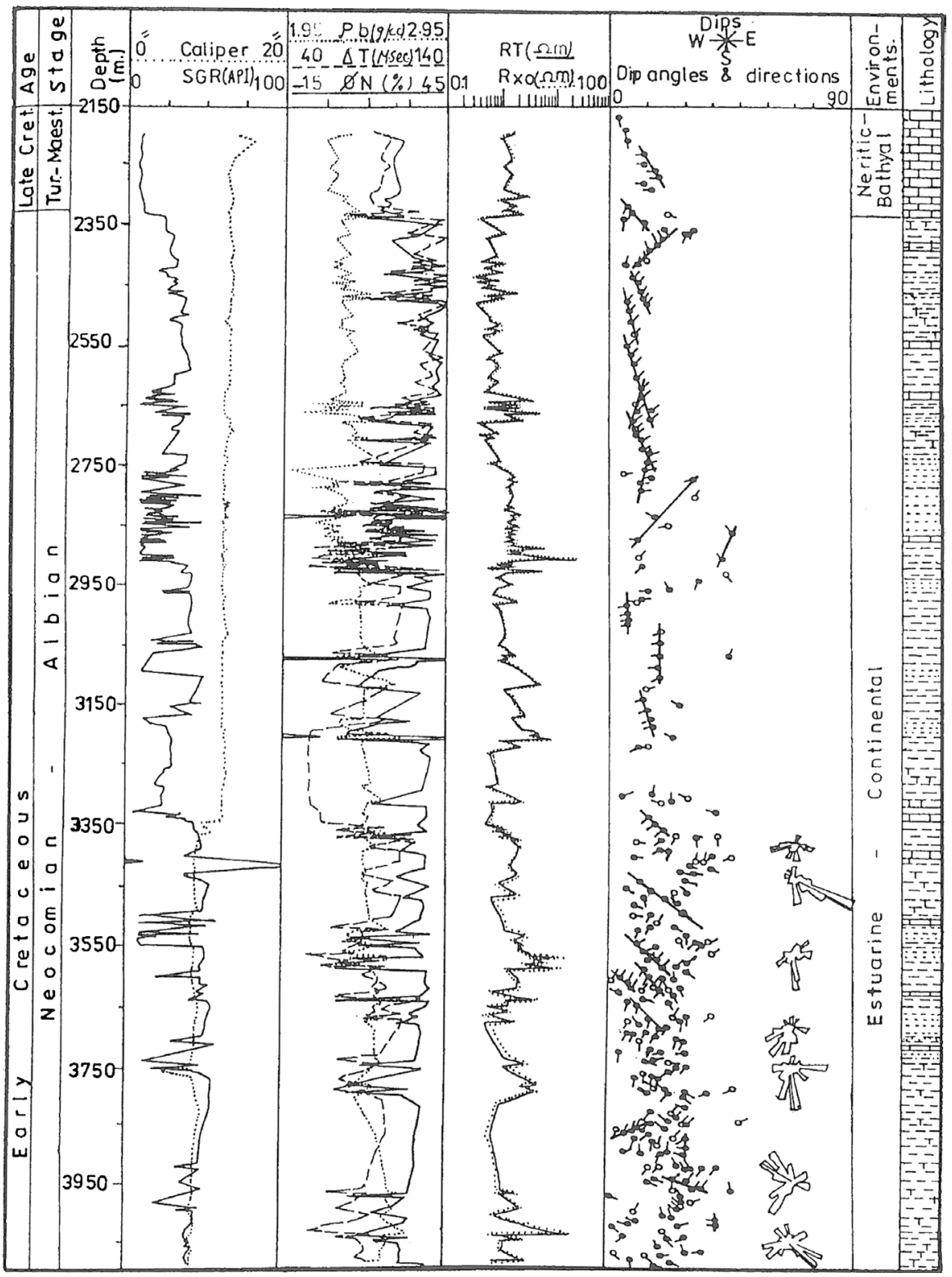

Figure 8. Interpreted depositional environments of the Cretaceous section based on the dipmeter patterns, the Mango-1 well. 


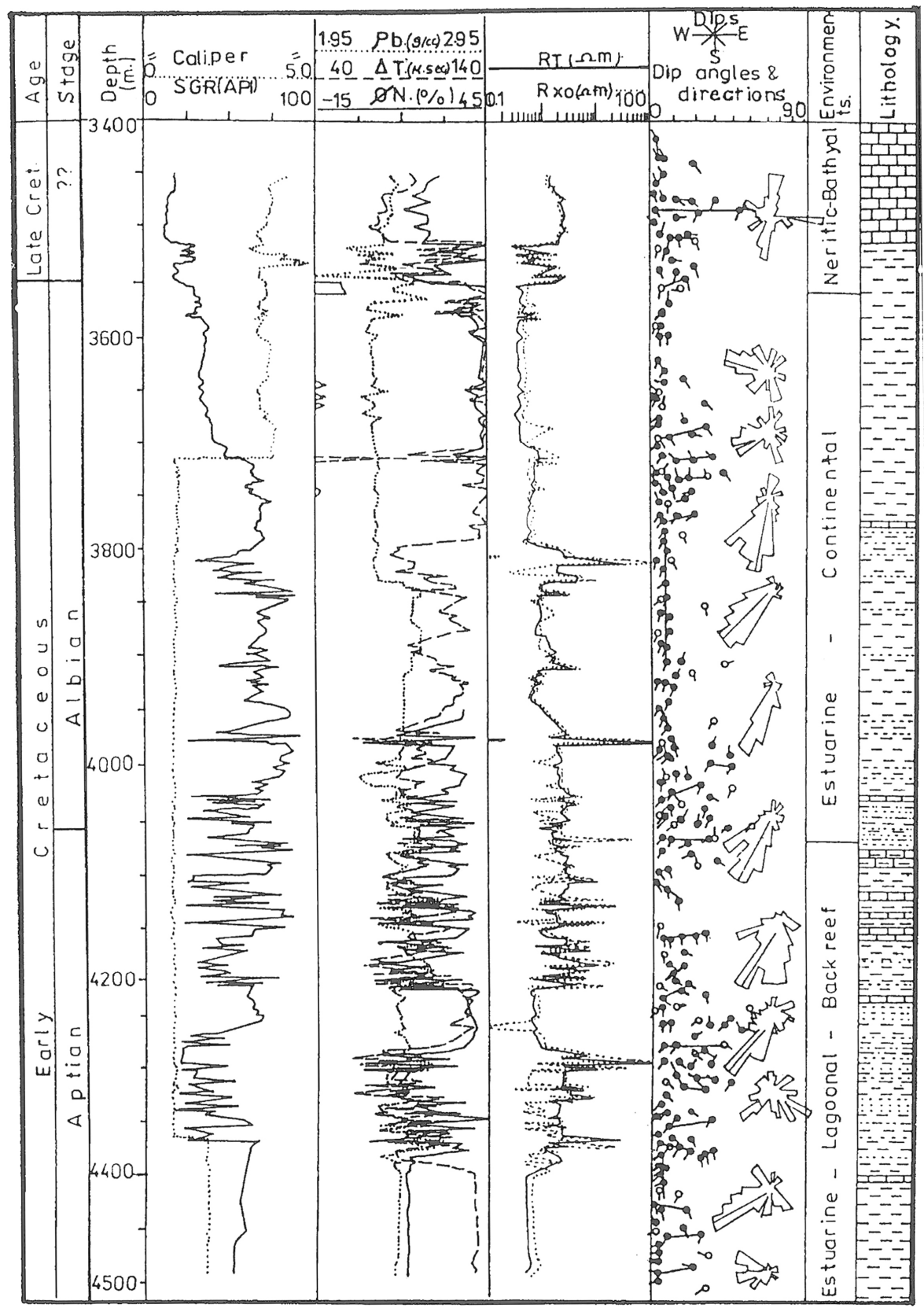

Figure 9. Interpreted depositional environments of the Cretaceous section based on the dipmeter patterns, the NS21-1 well.

interval (3760 - $4090 \mathrm{~m})$ is very laminated on the HDT curves at a low resistivity level, generating a lot of dips with scattered azimuth and low to moderate radioactivity. It could reflect reworking of sediments due to bioturbations. These observations suggest a very thinly laminated intervals and a relatively high clay percentage. Consequently, one can deduce numerous intercalation of this silt and/or sand beds (corresponding to some resistive continuous events) in the shale (Figure 10). However, some blue and red patterns occur which can correspond to foresets or cut and fill features.

The dips patterns (Figure 8 and Figure 9) are utilized to correlate the 


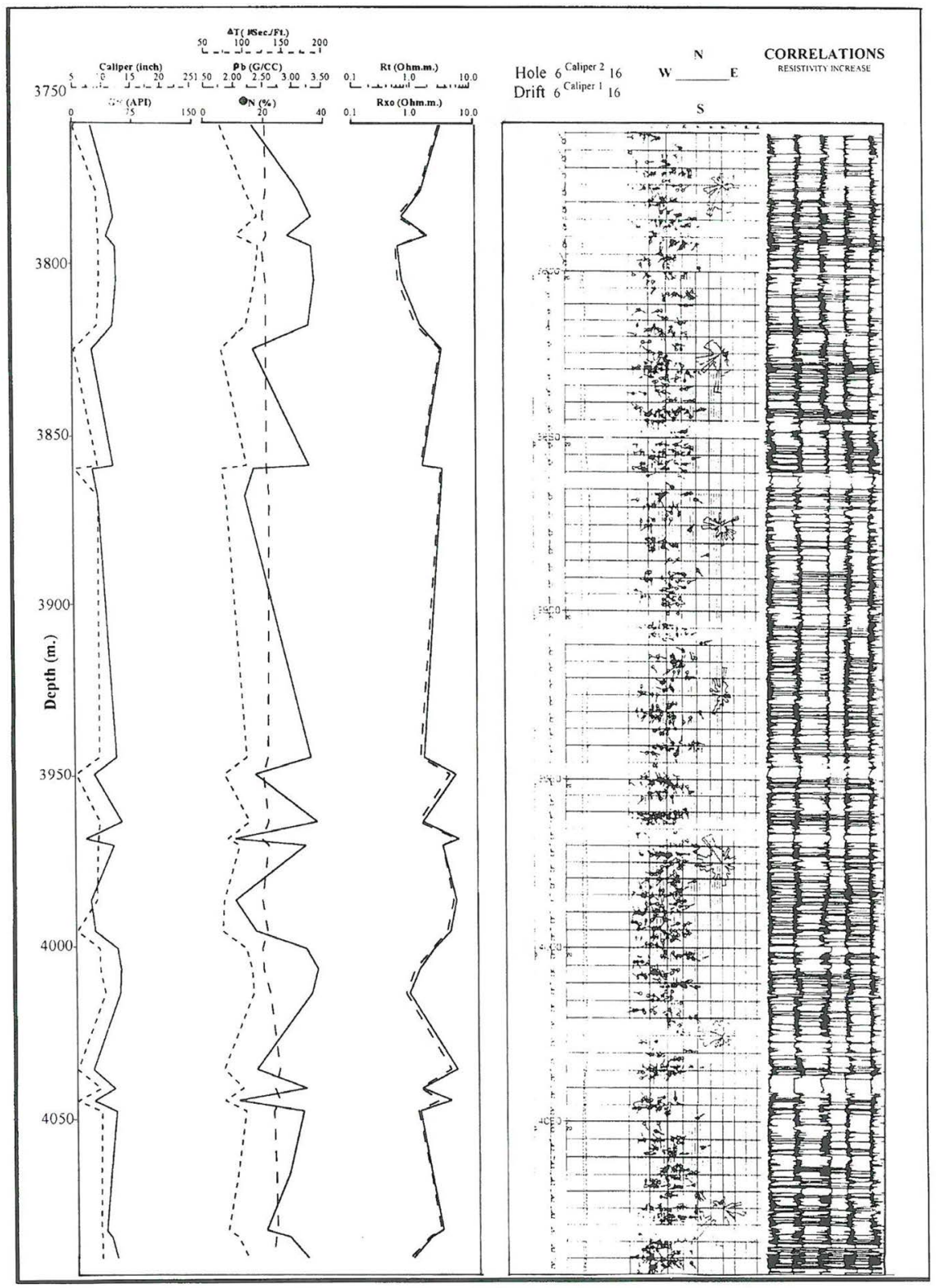

Figure 10. Example interval (3760 - $4090 \mathrm{~m})$ of the dual dip compared with the well logs of the Early Cretaceous section, the Mango-1 well.

mathematical functions required for defining the correlation parameters such as correlation interval, search angle and step distance. These parameters are needed to compute the depth ranges of the sea level during deposition. In that regard, depths which range from zero to $10 \mathrm{~m}$ indicate estuarine to deltaic environments, from $10 \mathrm{~m}$ to $20 \mathrm{~m}$ reflect lagoonal to back-reef environments, from $20 \mathrm{~m}$ to $100 \mathrm{~m}$ reveal reefal environments. Depth which varies from $100 \mathrm{~m}$ to $200 \mathrm{~m}$ show littoral to fore-reef environments, from $200 \mathrm{~m}$ to $500 \mathrm{~m}$ exhibit neritic environments, from $500 \mathrm{~m}$ to $2000 \mathrm{~m}$ suggest bathyal environments and depths which exceed $2000 \mathrm{~m}$ represent abyssal environments [13].

However, the dipmeter patterns are used to locate the formation boundaries 
and its major sedimentary subdivisions. The parallel to subparallel dipmeter patterns indicates continental conditions. Subparallel to divergent patterns reflect fluvio-marine conditions whereas bimodal to oblique patterns reflect shallow marine conditions. Simple to complex patterns show intermediate marine conditions; asymmetrical to irregular patterns exhibit outer deep marine conditions and chaotic to contorted pattern imply inner deep marine conditions. The relations between the dipmeter patterns and the depositional environments are shown in Figure 11(a) [13].

The resistivity, density, sonic, neutron and gamma ray logs are used to define the rock associations that accumulated under the different sedimentary conditions and to recognize the environments of deposition. Sands and gravels of the continental facies are coastal plain sediments. Sands and clays of the fluvio-marine facies are shelf sediments, sandstones, evaporites and reefs are of the shallow marine facies. Sandstone, shales and marls of the intermediate marine facies are of slope sediments, and shales and bedded limestone, as well as chalk and massif limestone are of deep open marine sediments.

The environmental interpretation of the Cretaceous section, based on these assumptions, revealed a complex system of depositional environments. The Early Cretaceous section has environments varying from estuarine to lagoonal and backreef for the Barremian-Aptian, and continental to estuarine for the

(a)

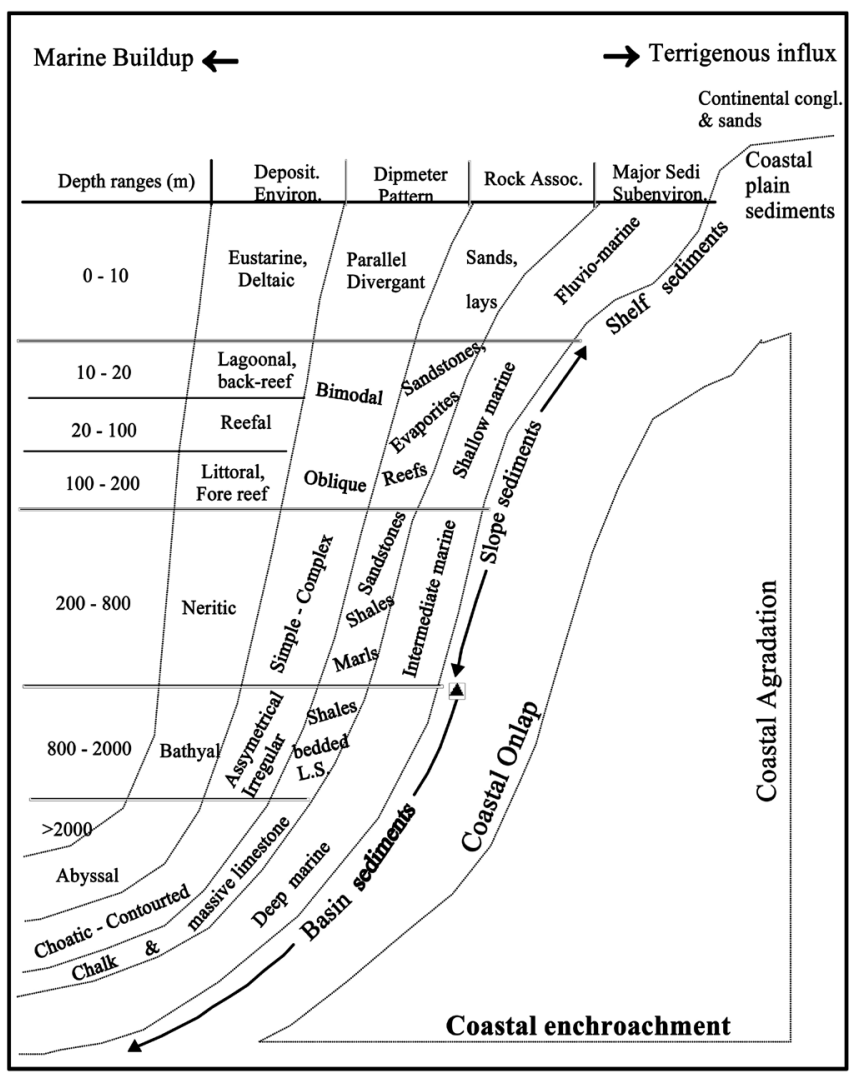

(c)

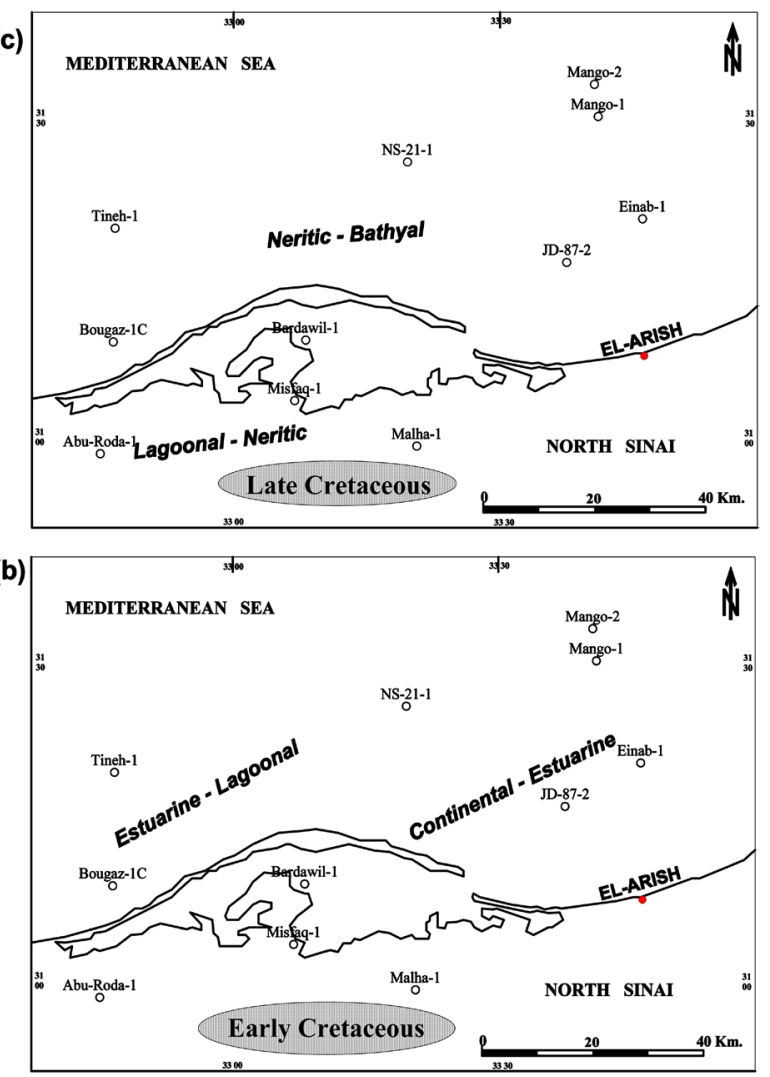

Figure 11. (a) Dipmeter patterns in relation to depositional environments and facies conditions ((b) \& (c)) Depositional environments of the Early and Late Cretaceous sections respectively, as deduced from dipmeter patterns analysis. 
Aptian-Albian (Figure 11(b)). These results can be correlated with the work of [14] who stated that, the Malha Formation (Aptian-Albian in age) represented mainly by carbonates seems to have been deposited under fluvio-parallic to shallow marine, with occasional high energy episodes.

By contrast, the Late Cretaceous sediments were accumulated in lagoonal to neritic and bathyal environments (Figure 11(c)). A sort of correlation has been found between the environmental interpretation of the dipmeter logs and that achieved based on the paleoecological studies of [15] who indicated that the Cenomanian transgression started very shallow allover Sinai and gradually became deeper to the north and the Turonian (represented by the Abu Qada Formation) accumulated under littoral conditions. However, the sea urchins and oysters recorded in the Late Cretaceous (Santonian) beds indicate deposition in littoral, inner neritic zone to outer shelf [14]. [16] stated that the foraminiferal assemblage of the Late Cretaceous (Maastrichtian) outcrops of northern Sinai denotes a shallow middle neritic environment with open sea conditions of the Early Maastrichtian, grading to shallow outer neritic and middle shelf water of the Late Maastrichtian.

The clay and detritus minerals have been identified using the diagram of [17] for clay mineral identification based on the $\mathrm{Th} / \mathrm{K}$ ratio. Applications of this diagram for the Cretaceous section of the available NGS-logged wells are represented in Figure 12(a) \& Figure 12(b). These applications revealed that illite, motmorillonite and micas form the majority of the Cretaceous clay minerals in most of the studied wells, with minor amounts of glauconite and chlorite. In the Mango-1 well, the detritus minerals are mainly potassium rich feldspars.

\section{2) Structural Interpretations}

The structural characteristics of the studied section are verified using the dipmeter logs and utilizing the graphical (dip grouping) and the analytical (Stereographic plotting) techniques. The dips computed by the dipmeter logs related to sedimentary structures can be selected and then evaluated with depth. In advance of reconstructing the original conditions, structural dips of five degrees or more, should be vertically removed. In that regard, the structural dips have to be taken from green patterns that correlate to shale rocks. Green patterns, which occur in sandstones, should be carefully investigated, because they may reflect dune crossbedding [15].

The analytical structural interpretation of the dipmeter data has been attempted using the stereographic projection and utilizing Schmidt stereonet. On the Schmidt stereonet, the planes are represented by their poles and dip values. The preferential grouping and orientation of these plots are based on dip and azimuth histograms of the dipmeter data (Figure 13(a) \& Figure 13(b)). These diagrams show that the Cretaceous section has dip values range from $0^{\circ}$ to $70^{\circ}$ with dispersed azimuths all over the study area (Figure 14(a)). This is mainly attributed to the folding and faulting deformations of the NE Syrian Arc System, not excluding sedimentary structures. 


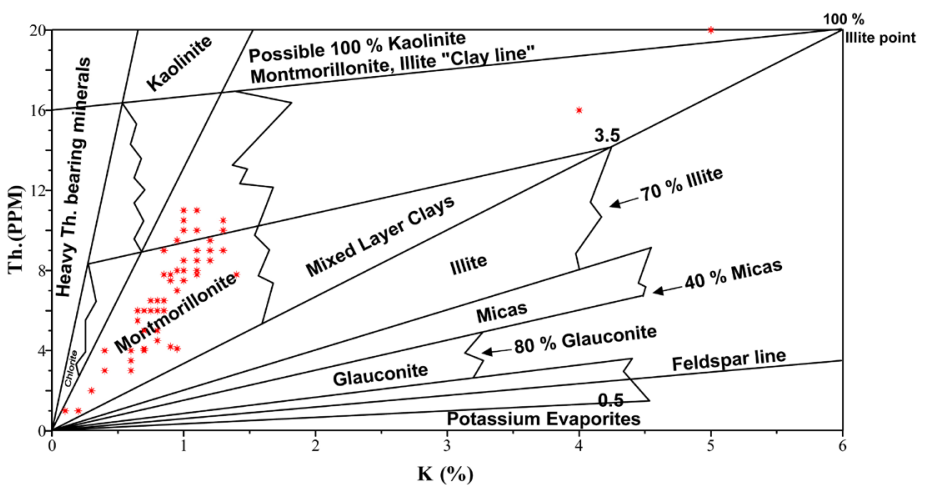

(a) Bardwail-1

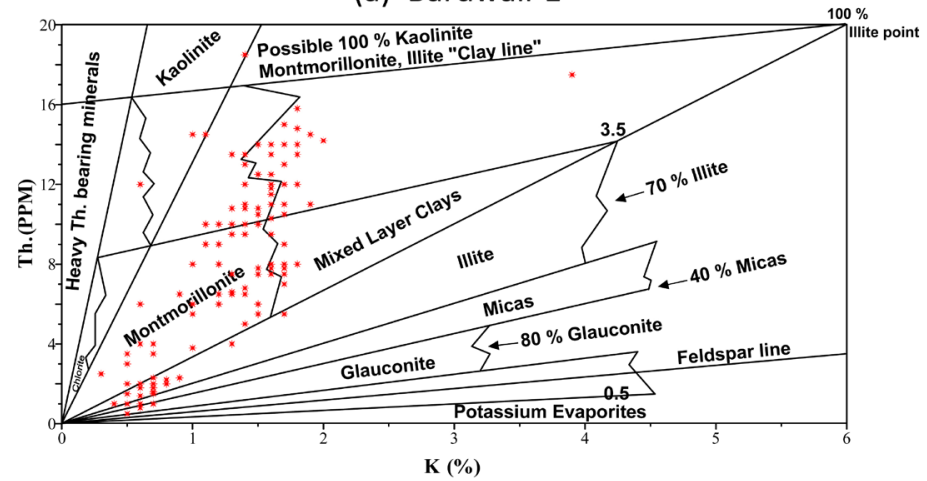

(b) JD-87-1

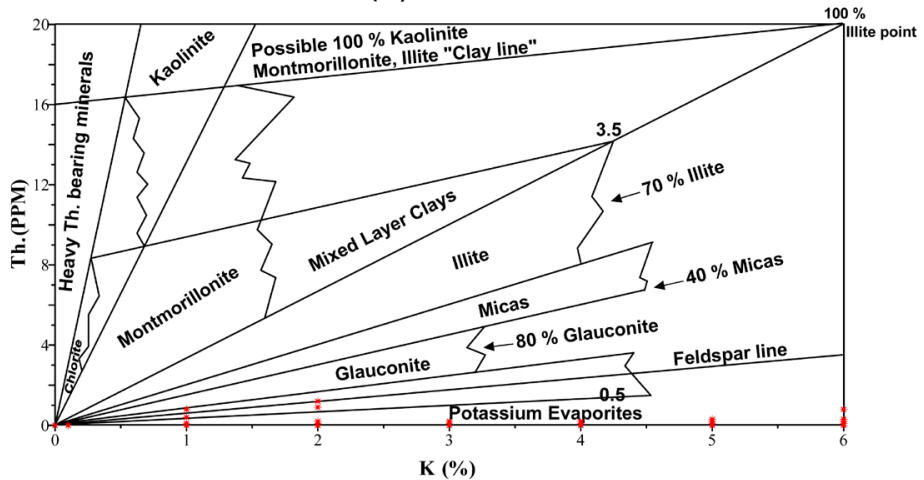

(c) Mango-1

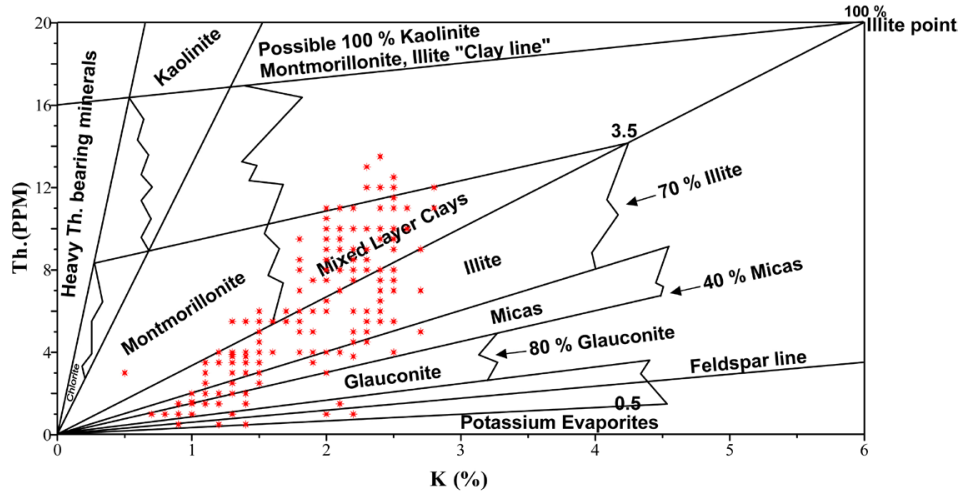

(d) NS-21-1

Figure 12. Identification of clay, detrital minerals and evaporates based on the $\mathrm{Th} / \mathrm{K}$ ratio of the Cretaceous sections of the Bardwail-1 (a), JD-87-1 (b), Mango-1 (c) and NS-21-1 (d) wells utilizing the diagram of [17]. 


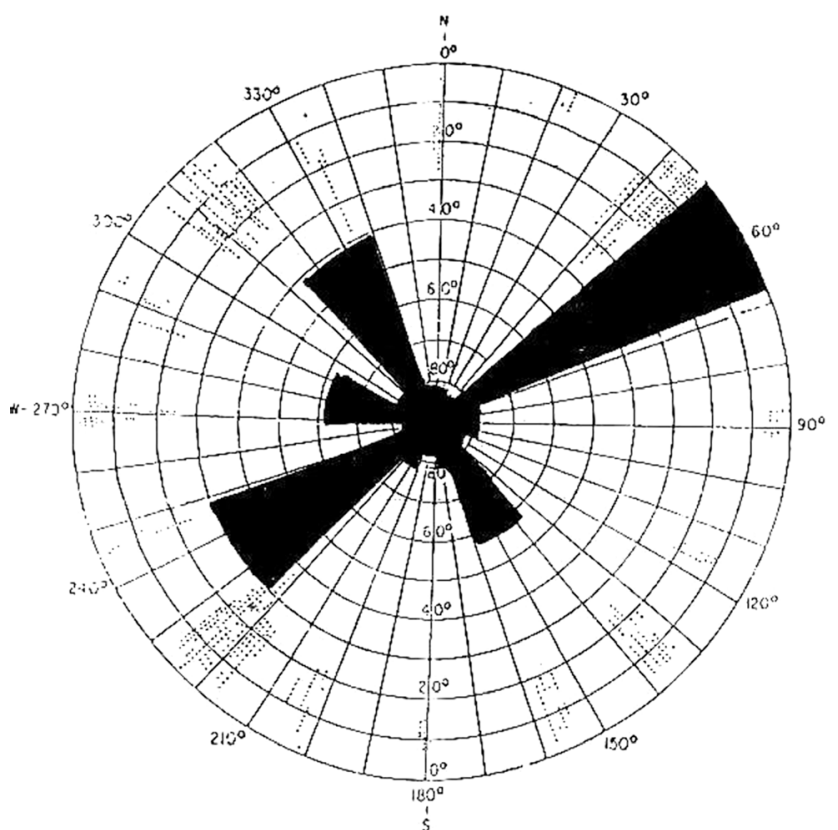

(a)

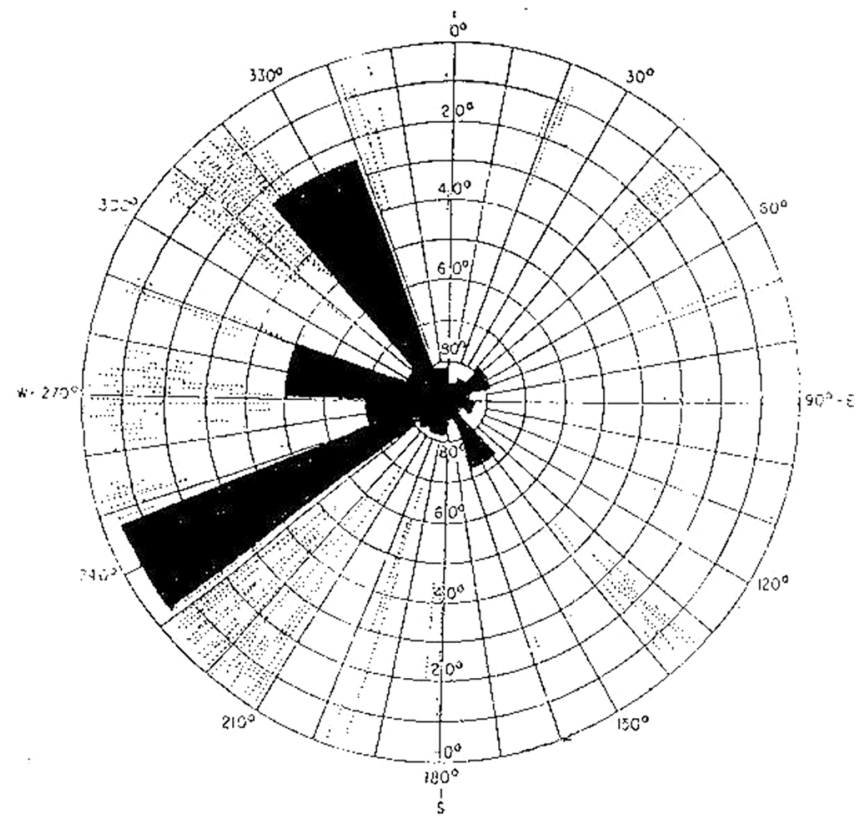

(b)

Figure 13. Polar frequency crossplots of the Cretaceous section utilizing Schmidt stereonet of the Mango-1 (a) and Bardawil-1 (b) wells.

The dipmeter derived structural dips are used for constructing two isobath maps for the Cretaceous section (Figure 14(b) \& Figure 14(c)). The isobath map, on the bottom of the Cretaceous section (Figure 14(b)), shows the structural dip values range from $5.6^{\circ}$ to $21^{\circ}$ all over the study area. This dip range has different azimuths; mainly $556^{\circ} \mathrm{W}$ at the eastern part of the area changing erratically at the western part toward the $\mathrm{W}, \mathrm{NW}$ and $\mathrm{E}$ directions. This pattern of the structural dips reflects the effect of the pre- and syn-Cretaceous tectonic events in controlling the bed attitudes. The distribution pattern of the contour lines (Figure 14(b)), indicates that the depocenter of the Early Cretaceous basin is strongly controlled by the Pelusium line traversing the study area in NE-SW direction and the Bardwail escarpment at the western part of the area, trending NW-SE.

The isobath map on top of the Cretaceous section (Figure 14(c)) shows structural dips range from $2^{\circ}$ to $21^{\circ}$ with a random azimuths all over the study area. These dip values are relatively low and completely different in azimuths from those detected at the bottom of the study section. This revealed a structural complexity of the studied section and probable syn-depositional rejuventaions along fault planes and not excluding rotations of the faulted blocks. This interpretation may be ascertained by comparison of the isopach maps (Figure 3) with these isobaths.

\section{Conclusions}

Integration of the subsurface geological data with the results of interpretation of the dipmeter (HDT and SHDT) and natural gamma ray spectrometry (NGS) 
(a)

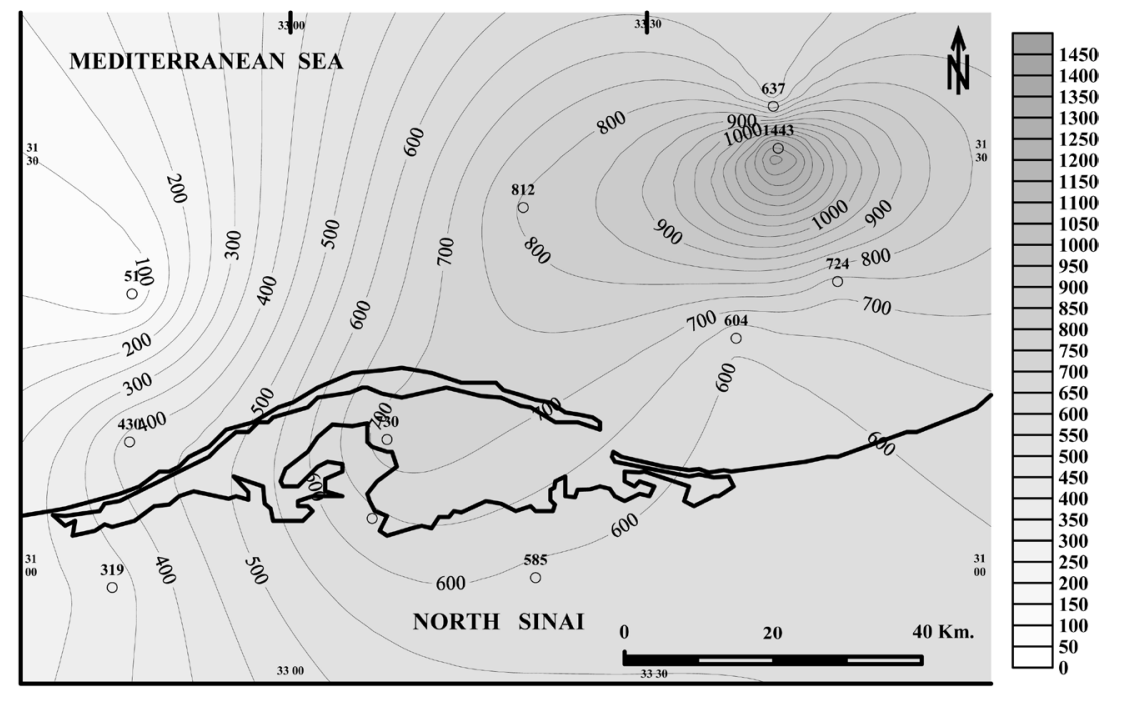

(b)

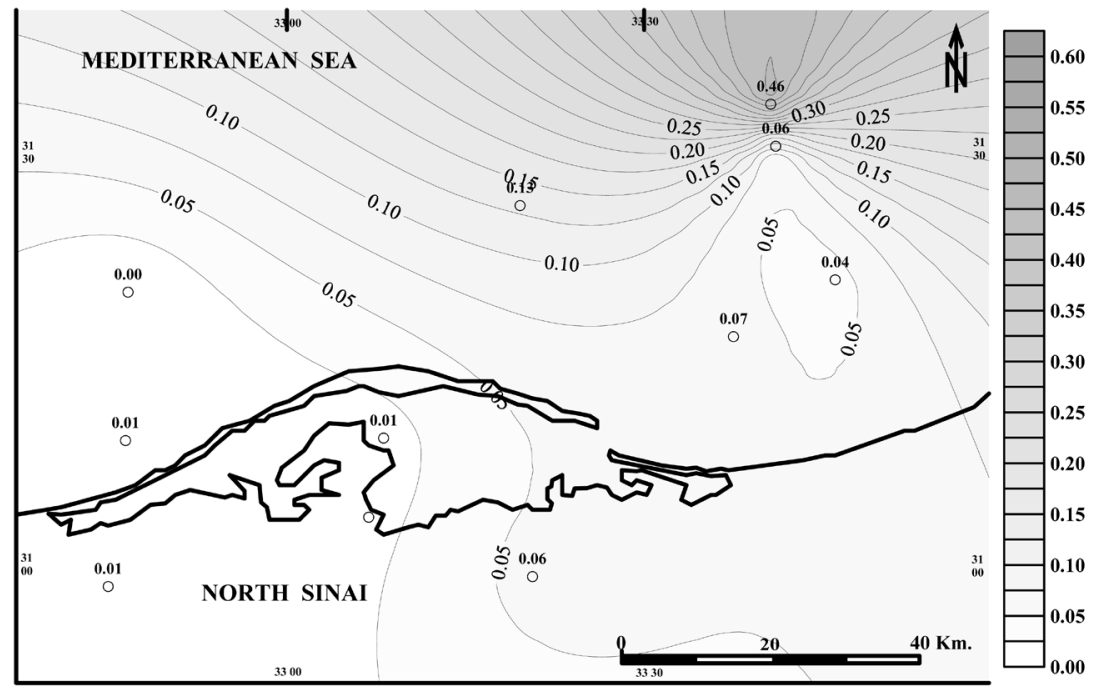

(c)

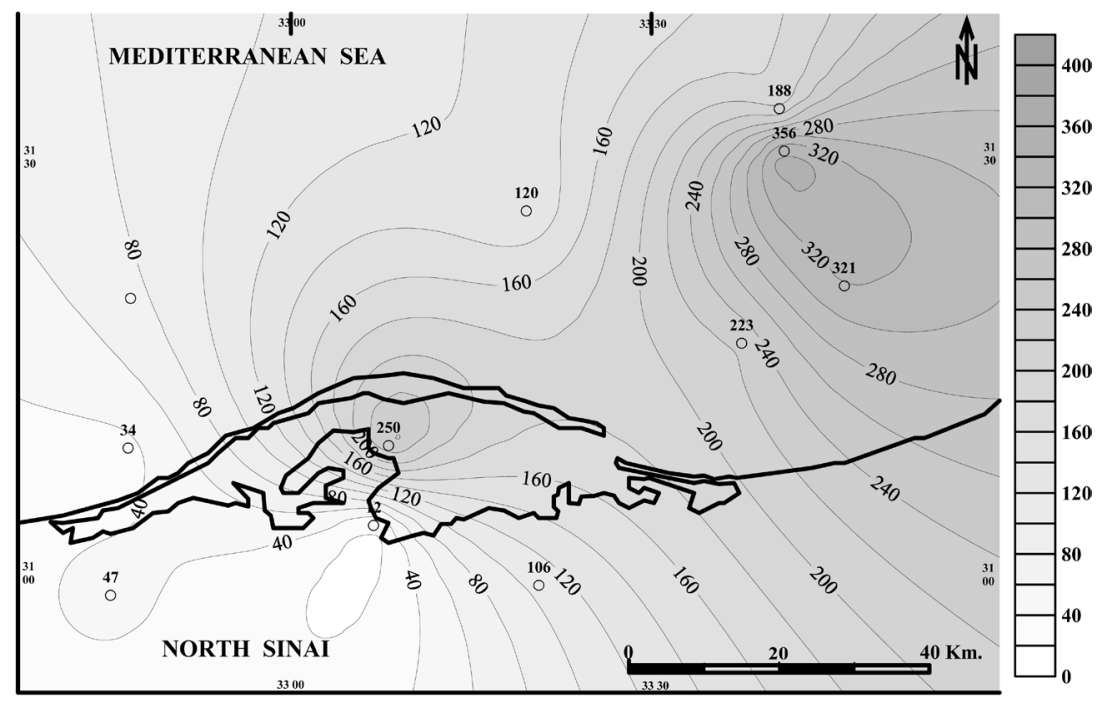

Figure 14. (a) A distribution map of the Frequency crossplots of the Cretaceous section. ((b) \& (c)) Dipmeter-based isobath maps on the top and bottom of the Cretaceous section, respectively. The arrows in the maps pointing to the dip directions and magnitudes. 
logs proved to be useful to define the depositional environment, facies changes and structural characteristics of the subsurface Cretaceous section. The interpretation of the dipmeter patterns and the NGS logs can be used for defining the depositional environments, while the Th/K logs of the NGS tool are used successfully for identifying the clay and detritus minerals of the studied interval.

This integrated study revealed a complex system of lithological composition and depositional environments of the subsurface Cretaceous section. The Early Cretaceous section (Neocomian, Aptian and Albian) is mainly composed of shales and marls with minor carbonate and sand intercalations. Based on the $\mathrm{Th} / \mathrm{K}$ ratios, the argillaceous sediments are composed of illite, montmorillonite and micas with little amounts of glauconite and chlorite. It was accumulated under environments varied from estuarine to lagoonal and backreef in the Barremian-Aptian rocks, and from continental to estuarine in the Aptian-Albian. By contrast, the Late Cretaceous section (mainly Cenomanian, Touronian, Santonian and Maastrichtian) is mainly composed of carbonates with little shale and marls intercalations. It was accumulated under environments varied from lagoonal to neritic and bathyal.

Structurally, the subsurface Cretaceous section attains a wide range of dip magnitudes $\left(0^{\circ}\right.$ to $\left.70^{\circ}\right)$ and dispersed azimuths all over the study area. These varied dip parameters, in addition to the distinct variation in the subsurface Cretaceous thickness all over the study area, may be attributed to a complex system of structural and sedimentological framework. The calculated structural dip values, ranging from $2^{\circ}$ to $21^{\circ}$ and of dispersed azimuths, indicate the structural complexity of the studied section. This structural complexity may attribute to syndepositional rejuvenations along old fault planes, not excluding rotation of the faulted blocks.

\section{Acknowledgements}

The authors are greatly indebted to the authorities of the Egyptian General Petroleum Corporation (EGPC) and the International Egyptian Oil Company (IEOC) for supplying the well logs.

\section{Conflicts of Interest}

The authors declare no conflicts of interest regarding the publication of this paper.

\section{References}

[1] Yousef, M., Moustafa, A.R. and Shann, M. (2010) Structural Setting and Tectonic Evolution of Offshore North Sinai, Egypt. Geological Society, London, Special Publications, 341, 65-84. https://doi.org/10.1144/SP341.4

[2] Al-Sharhan, A.S. and Salah, M.G. (1996) Geologic Setting and Hydrocarbon Potential of North Sinai, Egypt. Bulletin of Canadian Petroleum Geology, 44, 615-631.

[3] Zaghloul, Z.M., El-Gamai, M.M., Shaaban, F.F. and Yousef, A.F. (2001) Plates Interactions and Petroleum Potentials in the Nile Delta. Proceedings of the 1 st Confe- 
rence on the Deltas, Modern and Ancient, Cairo, 13-20 March 1999, 41-53.

[4] Dolson, J.C., Shann, M.V., Matbouly, S.I., Hammouda, H. and Rashed, R.M. (2001) Egypt in the Twenty-First Century; Petroleum Potential in Offshore Trend. GeoArabia, 6, 211-230.

[5] Abdel-Rahman, A.Y. (2013) Thermal Maturity and Hydrocarbon Potential of Jurassic Sediments, Northeastern Sinai, Egypt. Middle-East Journal of Scientific Research, 18, 183-190.

[6] Issawi, B., El-hinnawi, M., Francis, M. and Mazhar, A. (1999) The Phanerozoic Geology of Egypt: A Geodynamic Approach. The Egyptian Geological Survey, Special Publication No. 76, Cairo, 462.

[7] Shaaban, F.F., Lutz, R., Littke, R., Bueker, C. and Odisho, K. (2006) Petroleum System in NE Egypt: Source Rock Evaluation and Basin Modelling Approach. Journal of Petroleum Geology (JPG), 29, 103-124. https://doi.org/10.1111/j.1747-5457.2006.00103.x

[8] Jenkins, D.A. (1990) North and Central Sinai. In: Said, R., Ed., The Geology of Egypt, A.A. Balkema, Rotterdam, 361-380.

[9] Serra, O. (1985) Sedimentary Environments from Wireline Logs. Schlumberger Limited, Paris.

[10] Serra, O. (1986) Stratigraphy, Tectonic and Multi-Well Studies Using Wireline Logs. Schlumberger Limited, Paris.

[11] Schlumberger (1982) Natural Gamma Ray Spectrometry. Essentials of N.G.S. Interpretation. Schlumberger Limited, Paris.

[12] Rider, M.H. (1986) The Geological Interpretation of Well Logs. John Wiley and Sons, New York, $175 \mathrm{p}$.

[13] Abu El Ata, A.S.A. (1989) The Role of the Dipmeter and Other Well Log Analysis in Defining the Depositional Environments and Facies Conditions of the West of Cairo Area, Western Desert, Egypt. Egyptian Geophysical Survey, The 7 th Annual Meeting, Cairo, March 1989, 112-129.

[14] Kerdany, M.T. and Cherif, O.H. (1990) Mesozoic. In: Said, R., Ed., The Geology of Egypt, A.A. Balkema, Rotterdam, 361-380.

[15] Issawi, B., Yehia, M. and El-Deftar, T. (1994) The Delineation of Sinai Water Basins by Using Lithofacies Isopach and Structural Contour Maps. 2nd Conference on the Geology of the Arab World, Cairo, 483-497.

[16] El-Dawy, M.H., Azab, M.M. and Dakrory, A.M. (1992) Biostratigraphy and Paleoecology of the Upper Cretaceous-Lower Tertiary in Gebel Sahaba, Northwest Sinai. Proceeding of the 3 rd Conference on the Geology of Sinai for Development, Ismailia, January 1992, 175-190.

[17] Quirein, J.A., Baldwin, J.L., Terry, R.L. and Hendrieks, M. (1981) Estimation of Clay Types and Volumes from Well Log Data. An Example of the Global Method. Society of Professional Well Log Analyst, 22nd Annual Symposium, Paper Q. 